\title{
Feeding tuna oil to the sow at different times during pregnancy has different effects on piglet long-chain polyunsaturated fatty acid composition at birth and subsequent growth
}

\author{
J. A. Rooke*, A. G. Sinclair and S. A. Edwards $\dagger$ \\ Animal Biology Division, Scottish Agricultural College, Craibstone Estate, Aberdeen AB21 9YA, UK \\ (Received 11 July 2000 - Revised 1 December 2000 - Accepted 13 January 2001)
}

\begin{abstract}
In an attempt to prevent decreases in piglet $20: 4 n-6$ status at birth while increasing $22: 6 n-3$ status, multiparous sows (eight per treatment) were allocated to one of three different treatments: a basal diet fed from day 63 of pregnancy to term; basal diet supplemented with tuna oil $(17.5 \mathrm{~g} / \mathrm{kg})$ from day 63 to day 91 and then basal diet alone from day 92 to term; basal diet alone from day 63 to day 91 and then basal diet supplemented with tuna oil from day 92 to term. Tuna oil supplementation increased mainly $22: 6 n-3$ intake. Supplementation with tuna oil between day 92 and term increased $22: 6 n-3$ to a greater extent in all piglet tissues (brain, liver, retina and the remaining carcass) at birth than supplementation with tuna oil between days 63 and 91. However, while piglet $20: 4 n-6$ decreased to a greater extent in liver and carcass when diets were supplemented with tuna oil between days 92 and term than between days 63 and 91 , in the brain and retina, the reverse was true; $20: 4 n-6$ was decreased to a greater extent between days 63 and 91 than between 92 and term. The effect of pregnancy nutrition on the growth of piglets until $7 \mathrm{~d}$ postweaning ( $35 \mathrm{~d}$ of age) was assessed after removing any residual effects of pregnancy treatment by cross-fostering some piglets at birth. Piglets, the diets of whose dams had been supplemented with tuna oil during pregnancy, grew faster during the first $35 \mathrm{~d}$ of life than the progeny of sows fed only the basal diet. Feeding tuna oil to sows at different times during pregnancy therefore did not prevent decreases in piglet $20: 4 n-6$ status at birth, but did suggest that changes in piglet brain $20: 4 n-6$ status between days 63 and 91 of pregnancy were not reversible by later nutrition. Supplementing the diet of the pregnant sow with tuna oil had beneficial effects on postnatal piglet growth.
\end{abstract}

Pregnancy: Dietary fatty acids: Piglet tissue fatty acids

Both pre- and immediate postweaning mortality of piglets are important sources of losses to the pig industry (Varley, 1995). Furthermore, poor growth in the same periods results in longer-term reductions in performance (Mahan \& Lepine, 1991). Long-chain essential fatty acids (chain length $>18$ ) of the $n-6$ and $n-3$ series are important for brain development and function (Uauy et al. 2000). Docosahexaenoic acid (22:6n-3) is a major constituent of synaptic end sites and may be necessary for the formation of mature synaptosomes, while arachidonic acid (20:4n-6) may be a second messenger (Kurlak \& Stephenson, 1999). In the pig, as in the human subject (Clandinin et al. 1980), brain growth and therefore accretion of $22: 6 n-3$ is greatest in the last third of pregnancy (Sweasey et al. 1976; Passingham, 1985) and continues into postnatal life. Since commercial pig diets are based on cereals that do not contain long-chain $n-3$ fatty acids, a contributory factor to low piglet viability at birth and subsequent growth may be an imbalance or deficiency of these acids in the diet of the pregnant sow.

Rooke et al. (1998, 1999) showed that including tuna oil in the diet of the pregnant sow for the last $28 \mathrm{~d}$ of pregnancy increased the proportions of $22: 6 n-3$ in the brain and retina of the newborn piglet, thereby demonstrating, in contrast to previous studies (Thulin et al. 1989; Ruwe et al. 1991), that specific fatty acids could cross the placenta in late pregnancy. In addition, Rooke et al. (2000) showed that offering the sow the essential fatty acid

\footnotetext{
Abbreviations: BB, basal diet only from day 63 of pregnancy to term; BT, basal-diet from day 63 to day 91 of pregnancy followed by tuna oil supplementation from day 92 to term; TB, basal diet from day 63 to day 91 of pregnancy followed by tuna oil supplementation day 92 to term. * Corresponding author: Dr J. A. Rooke, fax + 44 (0) 1224711292 , email j.rooke@ab.sac.ac.uk

$\dagger$ Present address: Department of Agriculture, University of Newcastle upon Tyne, Newcastle NE1 7RU, UK.
} 
$18: 3 n-3$ throughout pregnancy resulted in substantially lower incorporation of $22: 6 n-3$ into piglet tissues at birth than obtained with tuna oil, indicating a limited biosynthetic capacity from $18: 3 n-3$. An observation common to all the earlier studies is that increasing incorporation of 22 : $6 n-3$ into piglet tissues is accompanied by reductions in $20: 4 n-6$. Since Carlson et al. (1992, 1993) have demonstrated poorer first-year growth in infants offered marine oils and correlated the depression in growth with $20: 4 n-6$ status, it is therefore desirable to prevent this reduction in $20: 4 n-6$. As most feed ingredients for pigs do not contain $20: 4 n-6$, approaches that may prevent this reduction in $20: 4 n-6$ resulting from feeding marine oils are: (1) variation in $n-6: n-3$ fatty acids in the diet or (2) the approach used here, which was to feed tuna oil at different stages of pregnancy with the expectation that supplementation with tuna oil during early rapid brain growth and then removal of the tuna oil from the diet for a period of time before parturition might prevent the decrease in proportions of $20: 4 n-6$ in piglet tissues. A secondary objective was to extend observations (Rooke et al. 2000) on the effect of offering different fatty acids to the sow during pregnancy on postnatal piglet growth, by measuring growth at weaning and changes in acute-phase protein concentrations, as these changes have been associated with the inappetance and check in growth that occurs at weaning (McCracken et al. 1995, 1999).

\section{Materials and methods}

\section{Animals}

The experiment was carried out at Tillycorthie Pig Unit, Scottish Agricultural College, Aberdeen. Twenty four multiparous sows (Large White $\times$ Landrace; Newsham Hybrid Pigs Ltd, Malton, North Yorkshire, UK; mean parity $3 \cdot 2$ (range $1-8$ ) were used in the experiment. The sows entered the experiment in four blocks of six sows, 63 (range 57-65) d after mating to Large White boars. Before the experiment the sows were fed $2.5 \mathrm{~kg}$ daily of a commercial dry sow diet. Sows were allocated to treatments (two sows per treatment per block) based on live weight and back-fat thickness.

\section{Experimental treatments}

The three experimental treatments consisted of two diets fed at different times during pregnancy. The first diet was a basal diet formulated to minimise inclusion of $n-3$ fatty acids containing $(\mathrm{g} / \mathrm{kg})$ : 340 ground maize, 205 milled wheat, 200 molassed sugarbeet pulp, 100 maize-gluten feed, 77 sunflower meal, 46 potato protein, 25 mineral and vitamin mix (Sowvite 110; Norvite Ltd, Insch, Aberdeenshire, UK), 6.5 monocalcium phosphate. The mineral and vitamin mix was fortified with $\alpha$-tocopheryl acetate (200 mg/kg diet) as an antioxidant. For the second diet, tuna oil (Tuna Orbital Oil; Scotia Pharmaceuticals Ltd, Carlisle, Cumbria, UK, $17.5 \mathrm{~g} / \mathrm{kg}$ diet) was added to the basal diet as a source of long-chain n-3 fatty acids, particularly $22: 6 n-3$. Batches of feed with added tuna oil were prepared twice weekly by mixing the oil with the basal diet in a $50 \mathrm{~kg}$ capacity horizontal mixer. The feed was stored with air excluded at room temperature in sealed plastic bags. The diets were offered in fixed daily amounts $(2.5 \mathrm{~kg} / \mathrm{d})$. Basal diet offered to the sows from day 63 until term comprised the first experimental treatment (BB). In the second treatment (TB), the tuna oil supplemented-diet was offered to the sows between days 63 and 91 of gestation and basal diet offered from day 92 to term. This order of feeding was reversed in the third treatment (BT), such that basal diet was offered to the sows between days 63 and 91 and then the diet supplemented with tuna oil between day 92 and term.

\section{Experimental procedures}

The experimental procedures were carried out under the Animal (Scientific Procedures) Act 1986 (Act of Parliament, 1986) and were subject to review by the Scottish Agricultural College Animal Experiments Committee.

Sows. The sows were weighed and back-fat thickness measured by ultrasonography at the $\mathrm{P}_{2}$ position on three occasions (days 63, 91 and 113 of gestation). Samples of blood and subcutaneous adipose tissue were obtained on days 63 and 91. Blood samples were obtained from each sow by jugular venepuncture into evacuated tubes containing KEDTA (18 mg). Plasma was prepared from the blood samples by centrifugation at $2000 \mathrm{~g}$ for $20 \mathrm{~min}$ and stored at $-20^{\circ} \mathrm{C}$ until analysed. Samples of subcutaneous adipose tissue were obtained by biopsy from two sites on the back of the sow (one site per sampling occasion). The sites were approximately $0.15 \mathrm{~m}$ posterior to the $\mathrm{P}_{2}$ site on either flank of the sow, approximately $0.25 \mathrm{~m}$ ventrally from the spine. Samples were obtained after sedating the sow and infusing local anaesthetic into the biopsy site; approximately $0.5 \mathrm{~g}$ tissue was obtained from the inner layer of subcutaneous adipose tissue. The sows were transferred to farrowing crates several days before parturition. On day 113 (range days 112-114) of pregnancy, sows were injected intramuscularly with $2 \mathrm{ml}$ of a synthetic prostaglandin analogue (cloprostenol; Planate; Coopers Animal Health, Crewe, Cheshire, UK, $92 \mathrm{mg} / \mathrm{ml}$ ) at about 11.00 hours to induce farrowing approximately $24 \mathrm{~h}$ thereafter. After farrowing sows were offered a commercial lactation diet which was increased by $0.5 \mathrm{~kg} / \mathrm{d}$ until the sows were offered food according to appetite.

Farrowing and piglets. All farrowings were attended. As each piglet was born, the times taken for the piglet to begin breathing, stand, reach the udder and successfully grasp a teat were recorded. On completion of the above measurements, the piglet was removed from the sow, dried and placed in a heated box to prevent consumption of colostrum. On completion of farrowing (30 min after expulsion of the placenta), the weight and sex of each piglet was recorded. From each litter, one (litter size eight or less) or two (litter size greater than eight) piglets were selected. The piglets selected were chosen to represent the mean litter weight while maintaining even weight groups for experimental allocation (see p. 23). Piglets were anaesthetised by intraperitoneal injection of sodium pentobarbitone (Euthatal; Rhone Merieux, Harlow, UK; $200 \mathrm{mg} / \mathrm{ml}$ ) and then immediately killed by an overdose of 
sodium pentobarbitone. The brain, liver and eyes were removed and the weights of liver and brain recorded. The eyes were freed from connective tissue and the anterior half of the eyeball and contents of the eye removed. The posterior half of the eyeball, liver and brain and the remainder of the carcass were stored at $-20^{\circ} \mathrm{C}$ until analysis.

Piglets post-farrowing. To separate the effects of preand postfarrowing nutrition on postnatal piglet growth, piglets were experimentally allocated at birth, before suckling was allowed. Each block of six sows was divided into two groups of three sows as the sows farrowed, in order to minimise the time piglets were separated from the sow; one sow in each group had been offered each experimental treatment. Nine piglets from each litter were divided into three groups of three piglets by weight and one piglet from each weight group allocated to a different foster mother. Where litter size prevented groups of triplicate piglets being formed, only six piglets (two groups of three) were experimentally allocated. Any piglets that were not experimentally allocated or killed were either retained with the dam or cross-fostered out of the group of three sows, so that within each group of three sows the total number and weight of piglets per sow were balanced. It was also not possible to form more than one group of sows from every block, either because sows farrowed unexpectedly early or over such an extended period of time that withholding colostrum from piglets from earlier farrowing sows may have prejudiced their welfare. In total, six groups of three sows were involved in experimental allocation, giving a total of fifty-one piglets for each treatment. Piglets were weighed weekly throughout a $28 \mathrm{~d}$ lactation and at $7 \mathrm{~d}$ after weaning. The piglets were weaned into flat-deck accommodation but maintained in their litter groups. Piglets were offered a weaning diet ad libitum; the diet was based on cooked cereals and was formulated to contain $(/ \mathrm{kg}) 16.5 \mathrm{MJ}$ digestible energy, $220 \mathrm{~g}$ crude protein $(\mathrm{N} \times 6.25)$ and $15.5 \mathrm{~g}$ lysine. At 28 and $35 \mathrm{~d}$ of age, blood samples were obtained from each piglet by jugular venepuncture into an evacuated tube containing heparin and plasma prepared as described earlier.

\section{Analytical procedures}

Food samples were analysed for DM $\left(80^{\circ} \mathrm{C}\right.$ for $\left.18 \mathrm{~h}\right)$, ash $\left(550^{\circ} \mathrm{C}\right.$ for $\left.18 \mathrm{~h}\right)$, crude protein by the Kjeldahl method and acid diethyl ether extract and neutral-detergent fibre according to Ministry of Agriculture, Fisheries and Food (1992). The estimated digestible energy concentrations of the diets were calculated according to Ministry of Agriculture, Fisheries and Food (1993). Piglet carcasses were minced and representative samples freeze-dried. Carcass DM was determined by freeze-drying, with correction for residual moisture. Carcass ash and crude protein were determined as earlier and lipid content by chloroform - methanol extraction as described by Atkinson et al. (1972).

Feed and tissue samples were homogenised in a suitable excess of chloroform-methanol $(2: 1, \mathrm{v} / \mathrm{v})$ containing pentadecanoic acid (15:0) as the internal standard and extracts of total lipid in chloroform were prepared. Samples of the posterior half of the eyeball were vigorously mixed with saline $(9 \mathrm{~g} \mathrm{NaCl} / \mathrm{l})$ to remove the retinal cells from connective tissue before extraction of the retinal cells. Fatty acid methyl esters were prepared by transmethylation by refluxing the lipid in methanol-toluene-sulphuric acid (20:10:1, by vol) for $30 \mathrm{~min}$. The fatty acid methyl esters were extracted into hexane before chromatography. Fatty acid methyl esters were separated by GLC using a capillary column (HP225, $30 \mathrm{~m} \times 0.25 \mathrm{~mm}$, film thickness $0.25 \mu \mathrm{m}$; Hewlett-Packard Ltd, Stockport, Cheshire, UK) in a Phillips PU4500 chromatograph. Peak identities were verified by comparison with the retention times of standard fatty acid methyl esters (Sigma Chemical Co. Ltd, Poole, Dorset, UK). Peak areas were determined with the aid of a Kontron DS450 Data System (Kontron Instruments, Watford, Herts., UK) and quantified with reference to the internal standard and a known standard (Supelco 37 Component mix; Supelco, Poole, Dorset).

Plasma haptoglobin measurement was based on the peroxidase activity of haptoglobin-methaemoglobin complexes (Skinner \& Roberts, 1994). Fibrinogen concentrations were measured by ELISA (Spurlock et al. 1997). Inter-and intra-assay CV were respectively 2.0 and $3.1 \%$ for haptoglobin and 4.5 and $11.6 \%$ for fibrinogen.

\section{Statistics}

A split-plot ANOVA, using Genstat 5 (1987 version, Lawes Agricultural Trust; Clarendon Press, Oxford, UK) with experimental treatment as the main effect and sampling time as a split plot, was used to analyse sow plasma and adipose tissue data. Since induction of farrowing was ineffective on three sows and tissue samples were obtained from either one or two piglets per litter the experimental design for data relating to piglet tissue composition was unbalanced; therefore, a randomised-block ANOVA, using the restricted maximum likelihood procedure of Genstat, was used to analyse these data and treatment effects assessed from Wald statistics and $\chi^{2}$ tests. Postnatal piglet growth and fibrinogen and haptoglobin concentrations were also analysed using the restricted maximum likelihood procedure; the model included the natural and foster mother of each piglet as random effects, experimental treatment of the natural mother and experimental treatment to which the foster mother of the piglet had been exposed during gestation (to assess residual effects of pregnancy diet) and their interaction as fixed factors, and piglet birth weight and weight at weaning as covariates where appropriate. The proportions of cross-fostered piglets dying or fostered out of the experiment because of ill thrift were analysed by cross-tabulation and $\chi^{2}$ tests.

\section{Results}

Diets

Adding tuna oil to the basal diet increased the acid diethyl ether extract concentration of the diet from 45 to $61 \mathrm{~g} / \mathrm{kg}$ $(P<0.01 ; n 4 ;$ SED 2.6$)$ and hence the calculated digestible energy concentration from $15 \cdot 1$ to $15 \cdot 3 \mathrm{MJ} / \mathrm{kg} \mathrm{DM}$ $(P<0.05 ; n$ 4; SED 0.036). Concentrations of DM 
Table 1. Fatty acid composition ( $\mathrm{g} / 100 \mathrm{~g}$ total fatty acids) of diets offered to sows with and without tuna oil $(7.5 \mathrm{~g} / \mathrm{kg})$

(Mean values with their pooled standard errors for four samples per diet)

\begin{tabular}{lccc}
\hline Diet & Basal & Tuna oil & SE \\
\hline Total fatty acids $(\mathrm{g} / \mathrm{kg} \mathrm{DM})$ & $28 \cdot 0$ & $46 \cdot 0$ & $1 \cdot 29$ \\
Total saturated & $19 \cdot 3$ & $22 \cdot 5$ & 0.43 \\
Monounsaturated & & & \\
$\quad$ Total & $19 \cdot 8$ & $17 \cdot 5$ & $0 \cdot 14$ \\
$18: 1 n-9$ & $18 \cdot 5$ & $13 \cdot 6$ & 0.22 \\
$n-6$ & & & \\
Total & $56 \cdot 7$ & $32 \cdot 8$ & 0.44 \\
$18: 2$ & $56 \cdot 4$ & $29 \cdot 3$ & 0.42 \\
$20: 4$ & $0 \cdot 3$ & $1 \cdot 1$ & 0.04 \\
$n-3$ & & & \\
Total & $4 \cdot 2$ & $27 \cdot 2$ & 0.32 \\
$18: 3$ & $3 \cdot 4$ & $2 \cdot 1$ & 0.04 \\
$20: 5$ & $0 \cdot 4$ & 3.5 & 0.08 \\
$22: 5$ & $\mathrm{ND}$ & $1 \cdot 1$ & 0.02 \\
$22: 6$ & $0 \cdot 1$ & 20.5 & 0.24 \\
$n-6: n-3$ & 13.7 & 1.2 & 0.64 \\
\hline
\end{tabular}

ND, none detected.

(887 g/kg; $n$ 8; SEM 1·2), crude protein (195 g/kg DM; $n 8$; SEM 2.6), neutral-detergent fibre (162 g/kg DM; $n$ 8; SEM $2 \cdot 0)$ and ash (73 g/kg DM; $n$ 8; SEM 1.1) did not differ significantly between diets. Adding tuna oil to the basal diet increased total fatty acids (Table 1) in the diet to a similar extent as acid diethyl ether extract concentration. The predominant fatty acid in the basal diet was $18: 2 n-6$, with only small proportions of $n-3$ acids present (mainly as $18: 3 n-3$ ). Adding tuna oil to the basal diet increased the proportion of $n-3$ fatty acids, mainly $22: 6 n-3$ and to a lesser extent $20: 5 n-3$.

\section{Sows}

The sows gained weight between days 60 and term: mean weights (kg; $n$ 24) were 235 (SEM 7.3), 248 (SEM 6.5) and
258 (SEM 6-2) on days 63, 92 and 113 respectively. Backfat thickness did not change significantly with time: mean thicknesses (mm; $n$ 24) were 21.6 (SEM 0.89), 21.0 (SEM 1.08 ) and 21.8 (SEM 0.86) at days 63, 92 and 113 respectively. Neither weight nor back fat thickness was influenced by the experimental treatments.

There were changes between days 63 and 91 in total plasma fatty acid concentrations and individual fatty acid proportions (Table 2). Irrespective of treatment, total fatty acid concentrations decreased and the proportions of $20: 4 n-6$ increased between days 63 and 91. There were treatment $\times$ time interactions for changes in long-chain $n-3$ fatty acid proportions. $20: 5 n-3$ increased in treatment $\mathrm{TB}$, but did not change consistently in treatments $\mathrm{BB}$ and BT. However, $22: 6 n-3$ increased in all treatments $(P<0.001)$ between days 63 and 91 ; the magnitude of the increase was much greater in treatment $\mathrm{TB}$ (interaction, $P<0 \cdot 001$ ).

In sow subcutaneous adipose tissue, changes in fatty acid proportions (Table 3) were less marked than those in plasma. Between days 63 and 91, the proportions of $20: 4 n-6$ decreased and of $18: 2 n-6$ and $18: 3 n-3$ increased irrespective of treatment. Overall treatment TB resulted in increased proportions of $20: 5 n-3$ and $22: 6 n-3$ in adipose tissue on day 91, while with treatments BB and BT these fatty acids either remained constant or tended to decrease. The ratio of $n-6: n-3$ fatty acids decreased between days 63 and 91 for treatment TB, while it tended to increase in treatments BB and BT (interaction, $P<0.05$ ).

\section{Piglets}

There were no differences in litter characteristics between treatments. Mean values $(n 24)$ for numbers of piglets born alive and piglet weight were 11.1 (SEM 0.74) and $1.34 \mathrm{~kg}$ (SEM 0.048). When the behaviour of the piglets (Table 4) was measured immediately after birth, piglets born to sows offered treatment BT tended to contact the udder $(P<0 \cdot 1)$

Table 2. Effects of including tuna oil in the diet of pregnant sows at different times during pregnancy on plasma fatty acids ( $\mathrm{g} / 100 \mathrm{~g}$ fatty acids) $\dagger$ (Mean values for eight observations)

\begin{tabular}{|c|c|c|c|c|c|c|c|c|c|c|}
\hline \multirow{2}{*}{$\begin{array}{l}\text { Treatment ... } \\
\text { Day ... }\end{array}$} & \multicolumn{2}{|c|}{ BB } & \multicolumn{2}{|c|}{ TB } & \multicolumn{2}{|c|}{ BT } & \multirow[b]{2}{*}{ SED } & \multicolumn{3}{|c|}{ Statistical significance of effect of: } \\
\hline & 63 & 91 & 63 & 91 & 63 & 91 & & Treatment & Time & Interaction \\
\hline Total saturated & $27 \cdot 0$ & $28 \cdot 3$ & 28.9 & $32 \cdot 0$ & $26 \cdot 4$ & $29 \cdot 5$ & $2 \cdot 32$ & NS & NS & NS \\
\hline \multicolumn{11}{|l|}{ Monounsaturated } \\
\hline Total & $24 \cdot 3$ & $24 \cdot 8$ & $29 \cdot 6$ & $23 \cdot 3$ & $26 \cdot 0$ & 24.5 & $1 \cdot 75$ & NS & * & NS \\
\hline $18: 1 n-9$ & 21.5 & 21.9 & 24.9 & $21 \cdot 3$ & 22.9 & $20 \cdot 9$ & 1.47 & NS & NS & NS \\
\hline \multicolumn{11}{|l|}{$n-6$} \\
\hline Total & $42 \cdot 9$ & 41.5 & $37 \cdot 1$ & $38 \cdot 3$ & $41 \cdot 3$ & $43 \cdot 1$ & $2 \cdot 87$ & * & NS & NS \\
\hline $18: 2$ & $38 \cdot 1$ & 35.9 & $32 \cdot 9$ & $33 \cdot 0$ & $36 \cdot 6$ & 35.6 & 2.96 & NS & NS & NS \\
\hline $20: 4$ & 3.4 & 3.8 & $2 \cdot 6$ & $2 \cdot 8$ & $3 \cdot 3$ & 3.5 & 0.60 & NS & * & NS \\
\hline \multicolumn{11}{|l|}{$n-3$} \\
\hline Total & $6 \cdot 8$ & $6 \cdot 7$ & $5 \cdot 9$ & 8.9 & $7 \cdot 2$ & $7 \cdot 1$ & 0.85 & NS & NS & * \\
\hline $18: 3$ & $5 \cdot 4$ & 4.5 & 4.5 & $4 \cdot 2$ & $5 \cdot 2$ & 4.5 & 0.48 & NS & * & NS \\
\hline $20: 5$ & 0.6 & 0.8 & 0.4 & $3 \cdot 1$ & $1 \cdot 2$ & 0.8 & 0.71 & NS & NS & $\star \star \star$ \\
\hline $22: 6$ & 0.4 & 0.9 & 0.4 & $3 \cdot 3$ & 0.5 & 0.6 & 0.44 & $\star *$ & *** & $\star \star \star *$ \\
\hline$n-6: n-3$ & 6.4 & $6 \cdot 2$ & $6 \cdot 4$ & 4.7 & $7 \cdot 2$ & $7 \cdot 1$ & 0.85 & NS & NS & * \\
\hline Concentration (mg/l) & 1510 & 1420 & 1920 & 1145 & 1840 & 1355 & 221 & NS & ** & NS \\
\hline
\end{tabular}

BB, basal diet only from day 63 of pregnancy to term; TB, tuna oil supplementation from day 63 to day 91 of pregnancy followed by basal diet from day 92 to term; BT, basal diet from day 63 to day 91 of pregnancy followed by tuna oil supplementation from day 92 to term.

${ }^{\star} P<0.05,{ }^{\star \star} P<0.01,{ }^{\star \star \star} P<0.001$.

$\dagger$ For details of treatments and procedures, see p. 22. 
Table 3. Effects of including tuna oil in the diet of pregnant sows at different times during pregnancy on subcutaneous adipose tissue fatty acids ( $\mathrm{g} / 100 \mathrm{~g}$ fatty acids) $\dagger$

(Mean values for eight observations)

\begin{tabular}{|c|c|c|c|c|c|c|c|c|c|c|}
\hline \multirow{2}{*}{$\begin{array}{l}\text { Treatment ... } \\
\text { Day ... }\end{array}$} & \multicolumn{2}{|c|}{ BB } & \multicolumn{2}{|c|}{ TB } & \multicolumn{2}{|c|}{ BT } & \multirow[b]{2}{*}{ SED } & \multicolumn{3}{|c|}{ Statistical significance of effect of } \\
\hline & 63 & 91 & 63 & 91 & 63 & 91 & & Treatment & Time & Interaction \\
\hline $\begin{array}{l}\text { Total saturated } \\
\text { Monounsaturated }\end{array}$ & $34 \cdot 2$ & $36 \cdot 1$ & 35.5 & $30 \cdot 6$ & $36 \cdot 1$ & $35 \cdot 3$ & $2 \cdot 42$ & NS & NS & NS \\
\hline Total & $37 \cdot 7$ & $40 \cdot 5$ & 41.6 & 39.9 & 41.5 & 41.5 & $2 \cdot 72$ & NS & NS & NS \\
\hline $\begin{array}{c}18: 1 n-9 \\
n-6\end{array}$ & 31.5 & $36 \cdot 3$ & $36 \cdot 3$ & $36 \cdot 1$ & $36 \cdot 2$ & 37.5 & $2 \cdot 33$ & NS & NS & NS \\
\hline Total & $18 \cdot 2$ & $20 \cdot 4$ & $20 \cdot 1$ & $20 \cdot 0$ & $19 \cdot 6$ & $20 \cdot 4$ & 1.68 & NS & NS & NS \\
\hline $18: 2$ & $14 \cdot 5$ & $19 \cdot 1$ & 14.9 & $18 \cdot 6$ & $15 \cdot 1$ & $18 \cdot 4$ & $2 \cdot 37$ & NS & $\stackrel{*}{*}$ & NS \\
\hline $\begin{array}{l}20: 4 \\
n-3\end{array}$ & 0.2 & 0.1 & 0.2 & 0.1 & 0.2 & 0.2 & 0.03 & NS & 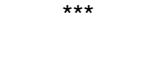 & NS \\
\hline Total & $2 \cdot 2$ & $2 \cdot 3$ & $2 \cdot 5$ & $2 \cdot 9$ & $2 \cdot 5$ & $2 \cdot 6$ & 0.24 & NS & $P=0.053$ & NS \\
\hline $18: 3$ & 1.9 & $2 \cdot 1$ & $2 \cdot 1$ & $2 \cdot 2$ & $2 \cdot 2$ & $2 \cdot 3$ & 0.19 & NS & NS & NS \\
\hline $20: 5$ & 0.1 & $<0.1$ & $<0.1$ & 0.1 & 0.1 & $<0.1$ & 0.02 & * & NS & $P=0.051$ \\
\hline $22: 6$ & 0.2 & 0.2 & 0.3 & 0.6 & 0.2 & 0.2 & 0.08 & $\star \star \star *$ & NS & * \\
\hline$n-6: n-3$ & 8.3 & 8.9 & 8.1 & $6 \cdot 8$ & $7 \cdot 8$ & 8.1 & 0.39 & * & NS & 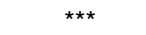 \\
\hline
\end{tabular}

BB, basal diet only from day 63 of pregnancy to term; TB, tuna oil supplementation from day 63 to day 91 of pregnancy followed by basal diet from day 92 to term; BT, basal diet from day 63 to day 91 of pregnancy followed by tuna oil supplementation from day 92 to term.

${ }^{\star} P<0.05 ;{ }^{* \star *} P<0.001$.

† For details of treatments and procedures, see p. 22.

and grasped a teat more quickly $(P<0.05)$ than the progeny of sows given treatments $\mathrm{BB}$ and $\mathrm{TB}$.

Feeding tuna oil to the sow at different times during gestation had different effects on piglet tissue fatty acid composition at birth. In the brain and retina (Table 5), tuna oil (treatments TB and BT) decreased $n-6$ and increased $n-3$ fatty acid proportions compared with treatment BB. For $n-6$ acids, treatment TB resulted in a greater depression in the proportions of $20: 4,22: 4$ and $22: 5 n-6$ than did treatment BT. In contrast, increases in $20: 5 n-3$ and $22: 6 n-3$ were greater for treatment BT than for treatment TB. The $22: 6 n-3 / 22: 5 n-6$ ratio was therefore increased to a greater extent by treatment TB than by treatment BT when compared with treatment BB. In general, changes in fatty acid composition as a result of treatment were less marked for the retina than the brain.

The different treatments imposed did not change the proximate composition of piglet carcasses (Table 6). The overall response of carcass and liver to the inclusion of tuna oil in the diet (treatments TB and BT) was similar to that of the brain and retina (see Table 5); the proportions of $n-6$ fatty acids were decreased and those of $n-3$ fatty acids increased when compared with treatment BB. The decreases in $n$ - 6 acids were confined to the long-chain $n$ - 6 acids $(20: 4,22: 4,22: 5 n-6)$ and, in contrast to the brain and retina, treatment $\mathrm{BT}$ resulted in a proportionately greater decrease in these fatty acids than did treatment TB. However, for the $n-3$ fatty acids, treatment BT increased $22: 6 n-3$ and $20: 5 n-3$ to a greater extent than did treatment $\mathrm{TB}$, in agreement with the response observed for the brain and retina. In contrast to the brain and retina, the ratio $22: 6 n-3$ to $22: 5 n-6$ was increased to a greater extent by treatment BT than by treatment TB.

\section{Piglet growth}

In Table 7 are given live weights for piglets experimentally allocated at birth, including piglets who remained with their natural mother. There were no residual effects of experimental treatment imposed during pregnancy mediated through colostrum and milk supply on the growth of piglets experimentally allocated at birth (see p. 23). Birth weight was a significant covariate for piglet weight at all ages and weight at weaning $(28 \mathrm{~d})$ a covariate for weight at

Table 4. Behavioural characteristics of piglets borne to sows fed tuna oil at different times during pregnancy† (Mean values for sixty observations)

\begin{tabular}{lccccc}
\hline Treatment ... & BB & TB & BT & SED & $\begin{array}{c}\text { Statistical significance } \\
\text { of treatment effect }\end{array}$ \\
\hline Time to: & 8 & 11 & 11 & 2.5 & NS \\
$\quad$ First breathe (s) & 1.3 & 1.3 & 1.4 & 0.37 & NS \\
Stand (min) & 12.6 & 13.4 & 11.1 & 2.96 & NS \\
Contact udder (min) & 25.1 & 26.2 & 20.7 & $2 \cdot 17$ & $*$ \\
Suckle (min) & & &
\end{tabular}

BB, basal diet only from day 63 of pregnancy to term; TB, tuna oil supplementation from day 63 to day 91 of pregnancy followed by basal diet from day 92 to term; BT, basal diet from day 63 to day 91 of pregnancy followed by tuna oil supplementation from day 92 to term.

${ }^{*} P<0.05$

† For details of treatments and procedures, see p. 22. 
Table 5. Fatty acid composition ( $\mathrm{g} / 100 \mathrm{~g}$ total fatty acids) of brain and retina from piglets borne to sows whose diets were supplemented with tuna oil at different times during pregnancy†

(Mean values for ten observations)

\begin{tabular}{|c|c|c|c|c|c|c|c|c|c|c|}
\hline \multirow[b]{2}{*}{ Treatment ... } & \multicolumn{3}{|c|}{ Brain } & \multirow[b]{2}{*}{ SED } & \multirow{2}{*}{$\begin{array}{l}\text { Statistical significance } \\
\text { of treatment effect }\end{array}$} & \multicolumn{3}{|c|}{ Retina } & \multirow[b]{2}{*}{ SED } & \multirow{2}{*}{$\begin{array}{c}\text { Statistical significance } \\
\text { of treatment effect }\end{array}$} \\
\hline & BB & TB & BT & & & BB & TB & BT & & \\
\hline Total saturated & $34 \cdot 2$ & 34.0 & 33.7 & 0.45 & NS & 41.7 & $42 \cdot 2$ & $42 \cdot 2$ & 1.84 & NS \\
\hline \multicolumn{11}{|l|}{ Monounsaturated } \\
\hline Total & 13.9 & $14 \cdot 7$ & $13 \cdot 8$ & 0.48 & NS & $17 \cdot 4$ & $18 \cdot 8$ & $17 \cdot 4$ & $1 \cdot 11$ & NS \\
\hline $18: 1 n-9$ & $9 \cdot 4$ & $10 \cdot 1$ & $9 \cdot 2$ & 0.37 & * & $12 \cdot 1$ & $12 \cdot 9$ & $12 \cdot 1$ & 0.76 & NS \\
\hline \multicolumn{11}{|l|}{$n-6$} \\
\hline Total & $30 \cdot 6$ & $27 \cdot 3$ & 28.9 & 0.66 & $\star \star \star \star ~$ & $19 \cdot 4$ & $16 \cdot 7$ & $18 \cdot 0$ & 1.01 & ** \\
\hline $18: 2$ & $4 \cdot 2$ & 4.5 & $4 \cdot 1$ & 0.16 & NS & $1 \cdot 11$ & $1 \cdot 24$ & $1 \cdot 10$ & 0.36 & NS \\
\hline $20: 4$ & $13 \cdot 6$ & $12 \cdot 4$ & $13 \cdot 2$ & 0.26 & 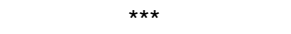 & 13.9 & 12.5 & $13 \cdot 2$ & 0.82 & NS \\
\hline $22: 4$ & $8 \cdot 1$ & $6 \cdot 9$ & $7 \cdot 4$ & 0.28 & $\star \star \star \star ~$ & $2 \cdot 13$ & 1.69 & 1.68 & 0.143 & $\star \star \star \star ~$ \\
\hline $22: 5$ & $4 \cdot 3$ & $2 \cdot 3$ & $3 \cdot 1$ & 0.35 & $\star \star \star \star$ & 1.60 & 1.03 & 1.14 & 0.118 & $\star \star \star \star ~$ \\
\hline \multicolumn{11}{|l|}{$n-3$} \\
\hline Total & $21 \cdot 4$ & $24 \cdot 0$ & $23 \cdot 9$ & 1.02 & $\star *$ & $21 \cdot 7$ & $22 \cdot 0$ & $22 \cdot 9$ & 1.87 & NS \\
\hline $18: 3$ & 0.7 & 0.7 & 0.7 & 0.03 & NS & & & & & \\
\hline $20: 5$ & 0.1 & 0.2 & 0.2 & 0.03 & $\star \star \star ~$ & 0.1 & 0.2 & 0.5 & 0.08 & *** \\
\hline $22: 5$ & $1 \cdot 1$ & $2 \cdot 1$ & 1.0 & 0.62 & NS & 0.2 & 0.6 & 0.7 & $0 \cdot 19$ & ** \\
\hline $22: 6$ & $19 \cdot 2$ & 21.1 & $22 \cdot 3$ & 0.53 & 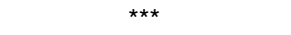 & $21 \cdot 1$ & $20 \cdot 9$ & 21.5 & 1.71 & NS \\
\hline$n-6: n-3$ & 1.5 & $1 \cdot 2$ & $1 \cdot 2$ & 0.07 & 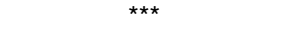 & 0.9 & $0 \cdot 8$ & 0.8 & 0.05 & * \\
\hline $22: 6 n-3: 22: 5 n-6$ & 4.6 & $9 \cdot 7$ & 7.5 & 0.72 & 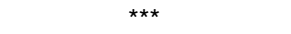 & $13 \cdot 6$ & $22 \cdot 5$ & $20 \cdot 7$ & $3 \cdot 21$ & ** \\
\hline
\end{tabular}

BB, basal diet only from day 63 of pregnancy to term; TB, tuna oil supplementation from day 63 to day 91 of pregnancy followed by basal diet from day 92 to term; BT, basal diet from day 63 to day 91 of pregnancy followed by tuna oil supplementation from day 92 to term.

${ }^{\star} P<0.05 ;{ }^{\star \star} P<0.01 ;{ }^{\star \star \star} P<0.001$.

$\dagger$ For details of treatments and procedures, see p. 23.

$35 \mathrm{~d}$ (1 week postweaning). There were significant differences between treatments in piglet weight (Table 7) at 14 and $28 \mathrm{~d}$ of age $(P<0.05$ in each case), with piglets borne to sows given treatment BT being heaviest at each age. At $35 \mathrm{~d}$ of age, piglets borne to sows given treatments TB and BT were heavier than those borne to sows fed treatment $\mathrm{BB}(P<0 \cdot 001)$. No between-treatment differences occurred in the percentage (overall 11.2) of piglets removed from the trial before weaning, either because they died (6.3) or were fostered off due to ill thrift (5). There were no differences between treatments in concentrations of the acute-phase proteins, haptoglobin and fibrinogen

Table 6. Fatty acid composition ( $\mathrm{g} / 100 \mathrm{~g}$ total fatty acids) of liver and carcass from piglets borne to sows whose diets were supplemented with tuna oil at different times during pregnancy†

(Mean values for ten observations)

\begin{tabular}{|c|c|c|c|c|c|c|c|c|c|c|}
\hline \multirow[b]{2}{*}{ Treatment ... } & \multicolumn{3}{|c|}{ Liver } & \multirow[b]{2}{*}{ SED } & \multirow{2}{*}{$\begin{array}{c}\text { Statistical significance } \\
\text { of treatment effect }\end{array}$} & \multicolumn{3}{|c|}{ Carcass } & \multirow[b]{2}{*}{ SED } & \multirow{2}{*}{$\begin{array}{l}\text { Statistical significance } \\
\text { of treatment effect }\end{array}$} \\
\hline & BB & TB & BT & & & BB & TB & BT & & \\
\hline Fat $(\mathrm{g} / \mathrm{kg})$ & & & & & & 65 & 70 & 68 & $2 \cdot 77$ & NS \\
\hline Protein $(\mathrm{g} / \mathrm{kg})$ & & & & & & 550 & 540 & 565 & 11.3 & NS \\
\hline Ash (g/kg) & & & & & & 194 & 196 & 188 & $10 \cdot 9$ & NS \\
\hline Total saturated & $33 \cdot 2$ & $31 \cdot 3$ & $32 \cdot 4$ & $1 \cdot 23$ & NS & 43.5 & 43.6 & $44 \cdot 6$ & 0.71 & NS \\
\hline \multicolumn{11}{|l|}{ Monounsaturated } \\
\hline Total & $27 \cdot 0$ & $30 \cdot 3$ & $28 \cdot 2$ & $2 \cdot 01$ & NS & $34 \cdot 2$ & $34 \cdot 3$ & $34 \cdot 6$ & 0.85 & NS \\
\hline $18: 1 n-9$ & $16 \cdot 3$ & $18 \cdot 1$ & $16 \cdot 8$ & $1 \cdot 29$ & NS & $20 \cdot 7$ & $20 \cdot 7$ & $20 \cdot 8$ & 0.55 & NS \\
\hline \multicolumn{11}{|l|}{$n-6$} \\
\hline Total & $25 \cdot 6$ & 24.9 & 23.0 & 2.04 & NS & $18 \cdot 3$ & $16 \cdot 5$ & 14.9 & 0.95 & ** \\
\hline $18: 2$ & $6 \cdot 4$ & $6 \cdot 8$ & $6 \cdot 0$ & 0.44 & NS & $5 \cdot 0$ & 4.8 & 4.4 & 0.29 & NS \\
\hline $20: 4$ & $15 \cdot 6$ & $13 \cdot 2$ & 11.4 & 1.31 & ** & 8.7 & 7.5 & 6.9 & 0.67 & * \\
\hline $22: 4$ & $1 \cdot 7$ & $1 \cdot 1$ & $1 \cdot 2$ & 0.26 & * & $1 \cdot 8$ & $1 \cdot 3$ & $1 \cdot 2$ & $0 \cdot 10$ & $\star \star \star \star ~$ \\
\hline $22: 5$ & $2 \cdot 7$ & $2 \cdot 1$ & 1.5 & 0.23 & 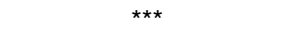 & 1.5 & $1 \cdot 3$ & 1.0 & 0.11 & *** \\
\hline \multicolumn{11}{|l|}{$n-3$} \\
\hline Total & $12 \cdot 8$ & $14 \cdot 4$ & $17 \cdot 3$ & 1.74 & * & 3.9 & $5 \cdot 7$ & $6 \cdot 0$ & 0.36 & $\star \star \star *$ \\
\hline $18: 3$ & 0.6 & 0.6 & 0.6 & 0.05 & NS & 0.1 & 0.3 & 0.2 & 0.16 & NS \\
\hline $20: 5$ & 0.9 & 1.5 & $2 \cdot 9$ & 0.21 & $\star \star \star \star ~$ & 0.4 & $0 \cdot 8$ & $1 \cdot 0$ & 0.11 & $\star \star \star \star ~$ \\
\hline $22: 5$ & 0.9 & $1 \cdot 3$ & 1.5 & 0.25 & * & 1.0 & $1 \cdot 3$ & 1.4 & 0.13 & * \\
\hline $22: 6$ & $10 \cdot 0$ & $10 \cdot 4$ & $13 \cdot 0$ & $1 \cdot 14$ & * & 2.5 & $3 \cdot 2$ & 3.4 & 0.30 & ** \\
\hline$n-6: n-3$ & $2 \cdot 1$ & 1.7 & 1.4 & 0.23 & * & $4 \cdot 7$ & 3.0 & $2 \cdot 6$ & 0.23 & $\star \star \star \star$ \\
\hline $22: 6 n-3: 22: 5 n-6$ & $3 \cdot 7$ & $5 \cdot 0$ & $8 \cdot 8$ & 0.80 & 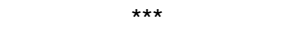 & $1 \cdot 7$ & $2 \cdot 6$ & $3 \cdot 3$ & 0.20 & $\star \star \star \star ~$ \\
\hline
\end{tabular}

BB, basal diet only from day 63 of pregnancy to term; TB, tuna oil supplementation from day 63 to day 91 of pregnancy followed by basal diet from day 92 to term; BT, basal diet from day 63 to day 91 of pregnancy followed by tuna oil supplementation from day 92 to term.

${ }^{\star} P<0.05 ;{ }^{* \star} P<0.01 ;{ }^{* \star \star} P<0.001$.

$\dagger$ For details of treatments and procedures, see p. 22. 
Table 7. Live weights of piglets and plasma haptoglobin and fibrinogen concentrations $(\mathrm{g} / \mathrm{l})$ in piglets which were the progeny of sows whose diets were supplemented with tuna oil at different times during pregnancy and experimentally allocated at birth $\dagger$

(Mean values for average of fifty-two ( $0 \mathrm{~d}$ ), forty-seven ( $7 \mathrm{~d}$ ) and forty-four (14, 21, 28, $35 \mathrm{~d}$ ) observations)

\begin{tabular}{|c|c|c|c|c|c|}
\hline & \multicolumn{3}{|c|}{ Pregnancy diet } & \multirow[b]{2}{*}{ SED } & \multirow{2}{*}{$\begin{array}{l}\text { Statistical significance } \\
\text { of treatment effect }\end{array}$} \\
\hline & BB & TB & BT & & \\
\hline \multicolumn{6}{|c|}{ Weight (kg) } \\
\hline $0 \mathrm{~d}$ & 1.40 & $1 \cdot 33$ & 1.45 & 0.096 & NS \\
\hline $7 d$ & 2.59 & $2 \cdot 72$ & $2 \cdot 75$ & 0.101 & NS \\
\hline $14 \mathrm{~d}$ & 4.47 & $4 \cdot 77$ & 4.94 & 0.193 & * \\
\hline $21 \mathrm{~d}$ & $6 \cdot 89$ & $6 \cdot 81$ & $6 \cdot 91$ & 0.245 & NS \\
\hline $28 d$ & $8 \cdot 24$ & $8 \cdot 74$ & $8 \cdot 85$ & 0.362 & * \\
\hline $35 \mathrm{~d}$ & $10 \cdot 09$ & $10 \cdot 25$ & $10 \cdot 18$ & $0 \cdot 101$ & $\star \star \star \star ~$ \\
\hline \multicolumn{6}{|c|}{ Haptoglobin } \\
\hline $28 \mathrm{~d}$ & 0.74 & 0.77 & 0.70 & 0.069 & NS \\
\hline $35 d$ & 0.69 & 0.60 & 0.67 & 0.078 & NS \\
\hline \multicolumn{6}{|c|}{ Fibrinogen } \\
\hline $28 \mathrm{~d}$ & $10 \cdot 8$ & 9.5 & $9 \cdot 4$ & 1.50 & NS \\
\hline $35 \mathrm{~d}$ & $10 \cdot 2$ & $10 \cdot 3$ & $11 \cdot 2$ & 0.91 & NS \\
\hline
\end{tabular}

BB, basal diet only from day 63 of pregnancy to term; TB, tuna oil supplementation from day 63 to day 91 of pregnancy followed by basal diet from day 92 to term; BT, basal diet from day 63 to day 91 of pregnancy followed by tuna oil supplementation from day 92 to term.

${ }^{*} P<0.05,{ }^{* \star *} P<0.001$.

† For details of treatments and procedures, see p. 22.

(Table 7). Haptoglobin concentrations decreased (paired $t$ test; $n$ 130; mean difference -0.09 ; SEM 0.039; $P=0.022$ ) and those of fibrinogen increased between weaning and $7 \mathrm{~d}$ postweaning (paired $t$ test; $n$ 113; mean difference 0.56 , SEM $0 \cdot 254, P=0 \cdot 028)$.

\section{Discussion}

\section{Piglet tissue fatty acid composition and tuna oil feeding}

The main objective was to investigate whether supplementation with tuna oil at an earlier stage of gestation and then removing the oil from the diet could achieve increases in $22: 6 n-3$ in piglet brain at birth without the potentiallyundesirable reductions in $20: 4 n-6$ observed in previous studies (Rooke et al. 1998, 1999, 2000) in which tuna oil was offered until the end of pregnancy. The rationale for this approach was that between days 60 and 88 of pregnancy the increase in piglet brain weight is approximately half that achieved between day 60 and term (Passingham, 1985; Farnworth \& Kramer, 1988). Thus, removal of $22: 6 n-3$ from the diet of the sow on day 92 might allow recovery from any decrease in the proportions of $20: 4 n-6$ between days 63 and 91 before birth, while still allowing increases in $22: 6 n-3$. This experimental approach does not seem to have been used previously, possibly because of the relatively short gestation length of small rodents. However, since changes in the proportions of $20: 4 n-6$ in tissues were accompanied by inverse changes in the proportions of $22: 6 n-3$, the experimental approach was ineffective in modifying piglet $20: 4 n-6$ status independent of $22: 6 n-3$ status. Unexpectedly, the reduction in $20: 4 n-6$ and $22: 5 n-6$ in the brain and retina was greater for treatment TB than for treatment BT, and might be an irreversible change in brain fatty acid composition with possible developmental consequences. It is difficult to extrapolate from changes in whole-brain fatty acid composition to functional changes. However, it may be relevant that while $22: 6 n-3$ is a major fatty acid in synaptic end sites, $20: 4 n-6$ occurs both in synaptic end sites and nerve growth cones (Kurlak \& Stephenson, 1999). As growth cones develop earlier than mature synaptosomes, the greater changes observed in brain $20: 4 n-6$ when tuna oil was fed from days 63 to 91 rather than day 92 to term could be related to this temporal relationship.

In addition to the different responses in brain $20: 4 n-6$ and $22: 6 n-3$ to treatments TB and BT discussed earlier, the question also arises whether the responses obtained with treatments $\mathrm{TB}$ and $\mathrm{BT}$ were additive. As a result of restrictions in sow availability, tuna oil was not offered continuously from day 60 to term in the present experiment. However, a basal diet consisting of the same ingredients and similar marine oil supplementation has

Table 8. Comparison of responses of long-chain fatty acids $(\mathrm{g} / 100 \mathrm{~g}$ fatty acids) in piglet brain at birth to supplementation of the maternal diet with marine oils in different experiments

\begin{tabular}{lcccc}
\hline Treatment $\ldots$ & Control & Marine oil & Difference & Sum TB + BT \\
\hline $22: 6 n-3$ & & & & \\
Expt $^{*}$ & & & & \\
$\quad 1$ & 13.3 & 15.6 & +2.3 & \\
2 & 17.8 & 19.8 & +2.0 & +5.0 \\
3: TB & 19.2 & 21.1 & +1.9 & \\
$\quad$ BT & 19.2 & 22.3 & +3.1 & \\
& & & & \\
$20: 4 n-6$ & & & & \\
Expt & & & & \\
1 & 11.2 & 9.5 & -1.7 & \\
2 & 15.7 & 13.9 & -1.8 & \\
3: TB & 13.6 & 12.4 & -1.2 & \\
$\quad$ BT & 13.6 & 13.2 & -0.4 & \\
\hline
\end{tabular}

TB, tuna oil supplementation from day 63 to day 91 of pregnancy followed by basal diet from day 92 to term; BT, basal diet from day 63 to day 91 of pregnancy followed by tuna oil supplementation from day 92 to term.

* Expt 1, Rooke et al. (2000); Expt 2; Rooke et al. (2001); Expt 3, present experiment. 
been used in other experiments. Rooke et al. (2000) offered tuna oil throughout gestation, while Rooke et al. (2001) fed salmon oil from day 60 to term. Table 8 summarises brain $20: 4 n-6$ and $22: 6 n-3$ composition in these experiments. The additive response in $20: 4 n-6$ for treatments BT and TB was similar to that observed for the entire period from day 60 to term (Rooke et al. 2000, 2001). However, the additive response in $22: 6 n-3$ for treatments TB and BT was greater than that observed when marine oil was fed continuously from day 60 to term. This comparison again suggests differences between $22: 6 n-3$ and $20: 4 n-6$ deposition in the brain. The effects of maternal nutrition on $n-6$ acids appear (because responses to treatments TB and BT are additive) to be time dependant, whereas there appears to be some capability to compensate for periods in which $22: 6 n-3$ is absent from the maternal diet.

\section{Fate of ingested $22: 6 n-3$}

Thulin et al. (1989), Ruwe et al. (1991) and Ramsay et al. (1991) concluded that there was little or no transfer of fatty acids across the porcine placenta in late pregnancy, which appears to conflict with the findings related to deposition of $22: 6 n-3$ in the present experiment. Since piglet carcass components and sow adipose tissue fatty acids were analysed in the present experiment, estimates could be made of the fate of dietary $22: 6 n-3$. Compared with a maternal intake of approximately $660 \mathrm{~g} 22: 6 n-3$ over $28 \mathrm{~d}$, the average increase in $22: 6 n-3$ was $0.9 \mathrm{~g} / \mathrm{kg}$ piglet live weight for treatments TB and BT (1.25- fold that of treatment BB). Since average total litter weight was $15 \mathrm{~kg}$, the net deposition of $22: 6 n-3$ in the litter was estimated as $13 \mathrm{~g}$ or 0.016 of maternal intake. This low $22: 6 n-3$ deposition is therefore compatible with the earlier reports. However, although the efficiency of deposition of maternal dietary $22: 6 n-3$ in fetal tissues was low, changes in piglet tissue $22: 6 n-3$ composition could not be obtained by feeding $18: 3 n-3$ (Rooke et al. 2000). The total amount of maternal lipid in the present experiment was estimated from Whittemore \& Yang (1989) to be approximately $60 \mathrm{~kg}$ lipid. Assuming body lipid mass remained constant for treatment TB between days 60 and 88, fatty acids comprised approximately $0 \cdot 8$ of total lipid and $22: 6 n-3$ increased by $0.27 \mathrm{~g} / 100 \mathrm{~g}$ fatty acids in adipose tissue, then the estimated deposition of $22: 6 n-3$ in adipose tissue was $130 \mathrm{~g}$ or 0.25 of intake. Thus, a substantial proportion of dietary $22: 6 n-3$ was unaccounted for in the present experiment and presumably oxidised. When the same estimate of $22: 6 n-3$ deposition in adipose tissue was made from Rooke et al. (2000) for the same dietary inclusion of 22 : $6 n-3$, but fed from day 4 to day 88 of pregnancy, a deposition of $940 \mathrm{~g}$ or 0.44 of intake was calculated. This difference in deposition of $22: 6 n-3$ between the two experiments is consistent with sows reconstituting body reserves in early gestation (when fetal demands are small) in contrast with later gestation (when fetal demands are greater) and raises the issue, not specifically addressed in the present experiment, of how reserves of fatty acids deposited in adipose tissue in early gestation may be utilised for fetal growth in late gestation. In the present experiment the proportions of $20: 4 n-6$ and $22: 6 n-3$ in the sow plasma increased and those in adipose tissue tended to decrease between day 63 and day 91 of pregnancy for sows fed BB, which suggests that mobilisation of longchain polyunsaturated fatty acids from adipose tissue may take place in late pregnancy. Whether this mobilisation of adipose tissue fatty acids is in line with the 'Relative mobilisation' of fatty acids proposed by Raclot and Groscolas (1993), whereby mobilisation is directly proportional to the degree of fatty acid unsaturation and inversely proportional to the fatty acid chain length or preferential mobilisation of $22: 6 n-3$, as observed in the chick embryo by Speake et al. (1997), cannot be concluded from the present experiment.

\section{Piglet growth}

There is increasing interest in how prenatal nutrition influences postnatal development (Cox, 1999). In this context Rooke et al. (2000) observed differences in liveweight gain between birth and $7 \mathrm{~d}$ postweaning in piglets whose dams were fed diets that contained different fatty acids both during pregnancy and lactation, and separated pre- and postnatal nutritional effects by experimentally allocating piglets at birth. A simpler model was used in the current experiment to investigate the effects of prenatal maternal fatty acid nutrition on postnatal piglet growth. Piglets were experimentally allocated at birth to quantify any carry-over effects (colostrum and milk derived) of pregnancy nutrition; in fact there were no significant carryover effects of pregnancy nutrition into lactation. However, at all stages of lactation, piglets whose dams had received treatments TB and BT during pregnancy (with treatment BT being numerically superior) were heavier than piglets whose dams had only received treatment $\mathrm{BB}$. This response in live-weight gain did not result from changes in lipid reserves at birth (as carcass lipid was unaltered by treatment) or to changed composition of the sow's milk (as this effect would have shown itself as a significant carry-over effect). Thus, the response in postnatal piglet growth to maternal nutrition during pregnancy must have been the result of improved piglet status at birth. In part, this effect may be explained by increased piglet vigour at birth as piglets from sows receiving treatment BT, but not treatment TB, reached the udder, and suckled more quickly. In addition, Cordoba et al. (2000) have observed reduced preweaning mortality in piglets borne to sows offered marine oil during pregnancy.

Piglets whose dam had been fed tuna oil during either pregnancy or lactation exhibited a reduced check in growth at weaning in a previous experiment (Rooke et al. 2000), which may have resulted from a reduction in an inflammatory response to the challenge of weaning as a result of feeding $n-3$ fatty acids (Grimble, 1998). Acutephase proteins have been measured as an index of the local intestinal inflammatory response that occurs at weaning (McCracken et al. 1995, 1999) and have also been used as an index of chronic immune system activation in the pig (Williams et al. 1997). Thus, in the present experiment concentrations of the acute-phase proteins haptoglobin and fibrinogen were measured at weaning and $7 \mathrm{~d}$ after weaning. No differences were observed between treatments 
in haptoglobin and fibrinogen concentrations at weaning, which is consistent with the lack of differences between treatments in the response of piglets to the weaning challenge. Increases in acute-phase protein concentrations between weaning and $7 \mathrm{~d}$ postweaning in the present experiment, of the extent normally associated with the acute-phase reaction (Kushner \& Mackiewicz, 1993) did not occur, suggesting that inflammatory reaction to the stress of weaning was not very marked.

In conclusion, supplementation of the diet of sows with tuna oil at different times during pregnancy had different effects on brain fatty acid status, but did not provide a method to prevent the reduction in brain $20: 4 n-6$ caused by feeding marine oil. Dietary tuna oil supplementation during pregnancy had positive effects on postnatal piglet growth.

\section{Acknowledgements}

We thank Vicki Bland and Hugh Hamilton and his staff for the care of the pigs and Morag Ewen and Ian McKay for technical assistance. The Scottish Agricultural College receives financial support from the Scottish Executive Rural Affairs Department. The authors are grateful to Scotia Pharmaceuticals for the gift of the tuna oil.

\section{References}

Act of Parliament (1986) Animal (Scientific Procedures) Act 1986. London: H.M. Stationery Office

Atkinson T, Fowler VR, Garten GA \& Lough AK (1972) A rapid method for the accurate determination of lipid in animal tissues. Analyst 97, 562-588.

Carlson SE, Cooke RJ, Werkman SH \& Tolley EA (1992) First year growth of preterm infants fed standard compared to marine oil n-3 supplemented formula. Lipids 27, 901-907.

Carlson SE, Werkman SH, Peeples JM, Cooke RJ \& Tolley EA (1993) Arachidonic acid status correlates with first year growth in preterm infants. Proceedings of the National Academy of Sciences USA 90, 1073-1077.

Clandinin MT, Chappell JE, Leong S, Heim T, Swyer PR \& Chance GW (1980) Intrauterine fatty acid accretion rates in human brain: implications for fatty acid requirements. Early Human Development 4, 121-129.

Cordoba R, Pkiyach S, Rooke JA, Edwards SA, Penny PC \& Pike I (2000) The effect of feeding salmon oil during pregnancy on causes of piglet deaths prior to weaning. In Proceedings of the British Society of Animal Science 2000, p. 105. Edinburgh, UK: British Society of Animal Science.

Cox SE (1999) The fetal origins hypothesis: an overview and implications. Nutrition Abstracts and Reviews 69A, 929-935.

Farnworth ER \& Kramer JKG (1988) Fetal pig development in sows fed diets containing different fats. Canadian Journal of Animal Science 68, 249-256.

Grimble RF (1998) Modification of inflammatory aspects of immune function by nutrients. Nutrition Research 7, 1297 1317

Kurlak LO \& Stephenson TJ (1999) Plausible explanations for effects of long-chain polyunsaturated fatty acids (LCPUFA) on neonates. Archives of Diseases in Childhood 80, F148-F154.

Kushner I \& Mackiewicz A (1993) The acute-phase response: an overview. In Acute Phase Proteins Molecular Biology, Biochemistry, and Clinical Applications, pp. 3-19 [A Mackiewicz, I Kushner and $\mathrm{H}$ Baumann, editors]. Boca Raton, FL: CRC Press.

McCracken BA, Gaskins HR, Ruwe-Kaiser PJ, Klasing KC \&
Jewell DE (1995) Diet-dependent and diet-independent metabolic responses underlie growth stasis of pigs at weaning. Journal of Nutrition 125, 2838-2845.

McCracken BA, Spurlock ME, Roos MA, Zuckermann FA \& Gaskins HR (1999) Weaning anorexia may contribute to local inflammation in the piglet small intestine. Journal of Nutrition 129, 613-619.

Mahan DC \& Lepine AJ (1991) Effect of pig weaning weight and associated nursery feeding programmes on subsequent performance to $105 \mathrm{kgs}$ body weight. Journal of Animal Science 69 , 1370-1378.

Ministry of Agriculture, Fisheries and Food (1992) Analysis of Agricultural Materials, 2nd ed. London: H.M. Stationery Office.

Ministry of Agriculture, Fisheries and Food (1993) Prediction of the Energy Value of Compound Feedingstuffs for Farm Animals. London: MAFF Publications

Passingham RE (1985) Rates of brain development in mammals including man. Brain, Behaviour and Evolution 26, 167-175.

Raclot T \& Groscolas R (1993) Differential mobilization of white adipose tissue fatty acids according to chain length, unsaturation, and positional isomerism. Journal of Lipid Research 54, 1513-1526.

Ramsay TG, Karousis J, White ME \& Wolverton CK (1991) Fatty acid metabolism by the porcine placenta. Journal of Animal Science 69, 3645-3654.

Rooke JA, Bland IM \& Edwards SA (1998) Effect of feeding tuna oil or soyabean oil as supplements to sows in late pregnancy on piglet tissue composition and viability. British Journal of Nutrition 80, 273-280.

Rooke JA, Bland IM \& Edwards SA (1999) Relationships between fatty acid status of sow plasma and that of umbilical cord and plasma and tissues of new-born piglets when sows were fed diets containing tuna oil or soyabean oil in late pregnancy. British Journal of Nutrition 82, 213-221.

Rooke JA, Shanks M \& Edwards SA (2000) Effect of offering maize, linseed or tuna oils throughout pregnancy and lactation on sow and piglet tissue composition and piglet performance. Animal Science 71, 289-299.

Rooke JA, Sinclair AG, Ewen M \& Birnie LM (2001) Responses in piglet tissue composition to increasing maternal intake of long chain $n-3$ polyunsaturated fatty acids. Proceedings of the Nutrition Society 60, 71A.

Ruwe PJ, Wolverton CK, White ME \& Ramsay TG (1991) Effect of maternal fasting on fetal and placental lipid metabolism in swine. Journal of Animal Science 69, 1935-1944.

Skinner JG \& Roberts L (1994) Haptoglobin as an indicator of infection in sheep. Veterinary Record 134, 33-36.

Speake BK, Cerolini C, Maldjian A \& Noble RC (1997) The preferential mobilisation of $\mathrm{C}_{20}$ and $\mathrm{C}_{22}$ polyunsaturated fatty acids from the adipose tissue of the chick embryo: potential implications regarding the provision of essential fatty acids for neural development. Biochimica et Biophysica Acta 1345, 317-326.

Spurlock ME, Frank GR, Willis GM, Kuske JL \& Cornelius SG (1997) Effect of dietary energy source and immunological challenge on growth performance and immunological variables in growing pigs. Journal of Animal Science 75, 720-726.

Sweasey D, Patterson DSP \& Glancy EM (1976) Biphasic myelination and the fatty acid composition of cerebrosides and cholesterol esters in the developing central nervous system of the domestic pig. Journal of Neurochemistry 27, 375-380.

Thulin AJ, Allee GL, Harmon DL \& Davis DL (1989) Uteroplacental transfer of octanoic, palmitic and linoleic acids during late gestation in gilts. Journal of Animal Science 67, 738-745.

Uauy R, Mena P \& Rojas C (2000) Essential fatty acids: structural 
and functional role. Proceedings of the Nutrition Society 59, $3-15$.

Varley M (1995) The Neonatal Pig. Development and Survival. Wallingford, Oxon.: CAB International.

Whittemore CT \& Yang H (1989) Physical and chemical composition of the body of breeding sows with differing body subcutaneous fat depth at parturition, differing nutrition during lactation and differing litter size. Animal Production 48, 203-212.

Williams NH, Stahly TS \& Zimmerman DR (1997) Effect of chronic immune system activation on the rate, efficiency, and composition of growth and lysine needs of pigs fed from 6 to $27 \mathrm{~kg}$. Journal of Animal Science 75, 2463-2471. 